\title{
CORRECTION
}

\section{Correction to: Invited Discussion on: Skin Reducing Mastectomy and Prepectoral Breast Reconstruction in Large Ptotic Breasts}

Ricardo Cavalcanti Ribeiro $^{1}$ - Ana Beatriz Spíndola Arduini ${ }^{1}$.

Luis Fernandez de Cordóva ${ }^{1}$ - Flávio Marques de Carvalho ${ }^{1}$

Published online: 6 May 2020

(C) Springer Science+Business Media, LLC, part of Springer Nature and International Society of Aesthetic Plastic Surgery 2020

\section{Correction to:}

\section{Aesth Plast Surg}

https://doi.org/10.1007/s00266-020-01709-y

Luis Fernandez de Cordóva's name appeared incorrectly in the original publication of this article. It appears correctly here.
Publisher's Note Springer Nature remains neutral with regard to jurisdictional claims in published maps and institutional affiliations.

The original article can be found online at https://doi.org/10.1007/ s00266-020-01709-y.

Ricardo Cavalcanti Ribeiro

rribeiro@centroin.net.br

1 Division of Plastic and Reconstructive Surgery, Universidade Federal Do Estado Do Rio de Janeiro, Rua Mariz e Barros, 775, Maracana, Rio de Janeiro, RJ, Brazil 